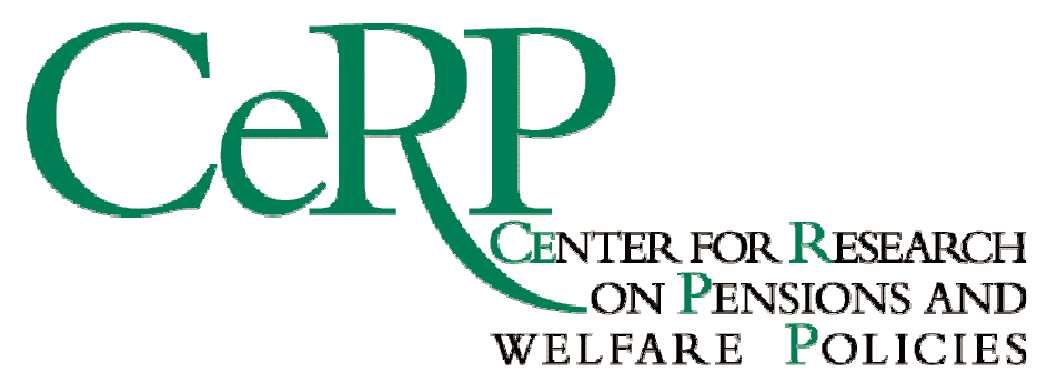

Working Paper 149/15

\title{
SHIFTING TAXES FROM LABOUR TO PROPERTY. A SIMULATION UNDER LABOUR MARKET EQUILIBRIUM
}

\author{
Flavia Coda Moscarola \\ Ugo Colombino \\ Francesco Figari \\ Marilena Locatelli
}




\title{
Shifting Taxes from Labour to Property. A Simulation under Labour Market Equilibrium ${ }^{1}$
}

\author{
Flavia Coda Moscarola, ${ }^{\mathrm{a} b}$ \\ Ugo Colombino $^{\mathrm{a}}$ \\ Francesco Figari $^{\mathrm{c}}$ \\ Marilena Locatelli ${ }^{\mathrm{a}}$ \\ ${ }^{\mathrm{a}}$ University of Turin \\ ${ }^{\mathrm{b}}$ Collegio Carlo Alberto \\ ${ }^{\mathrm{C}}$ University of Insubria, and ISER University of Essex,
}

\begin{abstract}
A tax shifting from labour income to housing taxation is generally advocated on efficiency grounds. However, most of the empirical literature focuses on the distributional implications of property tax reforms without paying much attention to potential consequences on the labour market. The aim of this paper is to fill this gap by investigating the effects of a tax shifting from labour income to property, guaranteeing revenue neutrality, and to assess the consequences of labour market equilibrium, both on occupation rates and income distribution. We propose to consider a hypothetical tax reform in Italy which uses the revenue of the tax on house property (actually implemented in 2012) for increasing tax credits on low incomes and making them refundable. In order to evaluate the reform we have developed a structural model of household labour supply which takes into account the labour market equilibrium conditions. Overall, the simulated policy provides a more effective income support and better incentives to work for low wage households and determines an improvement in inequality indexes.
\end{abstract}

JEL classification: C35, C53, D31, J22, H31

Keywords: labour supply, tax shifting, personal tax on labour income, property tax, labour market equilibrium, microsimulation

\section{Corresponding author:}

Flavia Coda Moscarola

E-mail: flavia.codamoscarola@carloalberto.org

\footnotetext{
1 This paper uses EUROMOD F6.36. The process of extending and updating EUROMOD is financially supported by the Directorate General for Employment, Social Affairs and Equal Opportunities of the European Commission [Progress grant no. VS/2011/0445]. We are grateful for access to microdata from the Italian component of the EU Statistics on Incomes and Living Conditions (ITSILC 2010) made available by Istat. We are indebted to Holly Sutherland and all members of the EUROMOD project for making EUROMOD freely accessible for research purposes. All results and their interpretation presented in this paper remain the authors' responsibility.
} 


\section{Introduction}

In the context of the financial and economic crisis governments are confronted with the need of consolidating their public finances but also of devising policy interventions aimed at fostering economic recovery and growth, taking into account equity concerns.

A general consensus seems to be reached on some general points. First, looking for tax bases less detrimental to growth, it looks reasonable to lower the tax burden on labour income. Second, distributional concerns are raised with respect to the protection of the most vulnerable groups of population, already severely hit by the crisis. At the same time, low-earners often face high implicit effective marginal tax rates due to the presence of means-tested benefits or non refundable tax relief schemes. Such provisions imply a very high tax burden on the additional earnings that a low-earner could try to get with strong disincentives on their labour supply.

It is here that the tax shifting from labour income to property comes into the picture. Property taxation is recognized as a form of taxation capable of raising tax revenues while being less harmful to economic efficiency and equity in the distribution of resources (European Commission, 2012; OECD, 2009; Mirrlees et al., 2011; IMF, 2013). Furthermore, the additional revenue obtained by a reform of the property taxation, if used to reduce the fiscal burden on low earners, could enhance both the efficiency and the equity of the fiscal system.

However, although a tax shifting to housing taxation is generally advocated on efficiency and redistributive grounds (Arnold et al., 2011; Norregaard, 2013), the existing empirical literature does not pay much attention to the potential consequences on the labour market that in turn also affect income distribution. The novelty of this paper is to fill this gap and to assess the consequences of the labour market equilibrium - both on occupation rates and income distribution - which could emerge as a result of a tax reform that shifts the tax burden from labour income to property, guaranteeing revenue neutrality.

In order to evaluate such a reform we have developed a structural model of household labour supply which takes into account the labour market equilibrium conditions. The analysis adds to the literature on ex ante evaluation of policy reforms as it simultaneously: a) encompasses a multisectorial perspective in order to better capture the heterogeneity in the workers population; b) adopts a modelling framework fully consistent with comparative static analysis considering the labour market equilibrium conditions; c) allows for revenue neutrality of the policy proposed. First we estimate the individual labour supply through a multi-sector discrete choice model: we build on Dagsvik and Strom (2006), Dagsvik et al. (2009) and Aaberge and Colombino (2013) by allowing individuals to choose, beside the hours of work (not working, part-time, full-time, extra-time) also, for the first time in the literature, the occupation (employment and selfemployment). Second, we account for market equilibrium conditions. Creedy and Duncan (2005) 
and Peichl and Siegloch (2012) complement a discrete choice model of labour supply by a model of labour demand. The procedure adopted there, however, would not be consistent with a matching model (as the one we adopt) that simultaneously includes a representation of both labour supply and labour demand. Here, therefore, we follow Colombino (2013), and adopt a procedure that is specifically appropriate for the estimated model and permits a consistent comparative static evaluation of pre- and post-reform equilibrium. Moreover, the parameters of the tax policies are calibrated in order to assure that the amount of net total tax revenues are equal to the pre-reform setting (fiscal neutrality).

We propose to consider a hypothetical tax reform in Italy, a country characterized by a relatively high tax burden on labour income, the absence of any generalized form of income support for the poorest and a renewed policy interest for property taxation (Longobardi, 2013). In particular, we simulate the new regime of property taxation as introduced in Italy in 2012. The new local property tax (i.e. IMU) applies different tax rates on the imputed value of both the main residence and other residences, allowing for some tax credits associated with the main residence and the presence of children. Focusing on households properties, the new property tax regime guarantees an extra tax revenue of about 8.5 billion euro. We do not take into account any potential effect on the housing market that could have emerged as a consequence of the new local property tax: this is consistent with a quite inelastic housing market in particular in Italy, a country characterized by a very low level of mobility.

In our simulations, such additional revenue is used to lower the personal income tax burden by increasing the amount of the existing tax credits for employees and self-employed and making them refundable. In this way, individuals with positive labour income can get a negative income tax if their tax liability is lower than the amount of the tax credits.

The results show an increase in the labour supply, in particular among women in couple, which contributes to enhance the redistributive effects of the simulated tax policy and to improve the overall social welfare. As expected, the labour market equilibrium determines a reduction of the positive labour supply effect of the reform which can be quantified in around one third and compresses the distributive effects. The results highlight the potential use of revenue of housing taxation to reduce the tax burden on labour income and the importance of accounting for second round effects in the simulations.

\section{The Italian tax burden on labour and property incomes}

As in the case of most European countries, the Italian tax benefit system is the result of historical compromises, designed under a given set of social and economic circumstances. Despite frequent periodic adjustments in the tax structure, the changes in the tax system have not provided a more competitive fiscal environment and better work incentives in particular for low-income earners. Considering both income tax and social insurance contributions, working-age individuals face 
quite a high levy compared to other European countries and they receive limited support from the benefit system. The average tax in Italy is about 10 percentage points higher than the OECD average (OECD, 2009), with a one-earner couple with two children facing a tax wedge of $36 \%$ (compared with an OECD average of 26\%) and a lone parent with two children facing a tax wedge of $25 \%$ (compared with an OECD average of $17 \%$ ).

The personal income tax is assessed at the individual level based on a progressive schedule, with the marginal tax rate set at $43 \%$. In the absence of any general tax relief (e.g. in the form of a personal allowance), tax payers can get a reduction of their tax burden only through non refundable personal tax credits related to the income source in addition to a number of tax reliefs that depend on the number of dependent persons in the family. Tax credits related to the income source constitute a no tax area for employees with an income up to 8000 per year and selfemployed with an income up to 4800 euro per year. Above these thresholds and up to 55,000 euro per year the tax credits are linearly decreasing in the level of gross income and exhaust when income is 55,000 euro per year. However, given that they are non refundable, low-income individuals do not receive the full amount of the tax credit if this exceeds the tax liability. Overall the existing direct taxes imply a quite low level of progressivity coupled with a relative high average tax (Verbist and Figari, 2014).

In this paper we consider a hypothetical reform that makes the tax credits more generous and refundable by using the extra revenue generated by the property tax reform introduced in Italy in 2012 which is about 8.5 euro billions including only the taxes on dwellings belonging to private households. The property tax was first introduced in Italy in 1992 as a municipal tax (ICI, Imposta Comunale sugli Immobili) on residential, commercial, and industrial buildings plus agricultural and residential land but since 2008 owner-occupied dwellings were exempted from the tax. As in the case of 1992, opposition to property tax reform was overcome in the context of a financial crisis (Longobardi, 2013) and in 2012 Italy introduced a new property tax (IMU, Imposta Municipale Unica) that fundamentally reformed and increased property taxation, including the owner-occupied dwellings into the tax base which is represented by the imputed values (i.e. the re-evaluated cadastral values) of the dwellings. The basic tax rate was set at 0.76 per cent but municipalities were permitted to alter the rate within $+/-0.3$ percent. The tax rate for primary residences was set at 0.4 per cent but municipalities were allowed to alter the rate within +/- 0.2 per cent. ${ }^{2}$ Overall, considering all properties in the country not only those owned by private households, the new measures resulted in a significant increase in property tax revenue which summed up to 24 euro billions in 2012 with respect to 10 euro billions in 2011. Considering the new property tax, the tax revenue from housing properties belonging to private households in 2012 was around $10 \%$ of tax revenue, a percentage still lower than what observed in France or the UK (OECD, 2014).

\footnotetext{
${ }^{2}$ In the simulation, due to lack of information on the municipality of residence the basic tax rate is applied.
} 
However, the tax on primary residences has been in place only for one year because it has been frozen and then abolished in the 2013. A full review of the housing taxation is again under consideration and the new tax will be more similar to a comprehensive service tax, resembling the British Council Tax and the French system of a tax foncière and a taxe d'habitation (Longobardi, 2013).

From a policy perspective, in this rather uncertain institutional context, our estimates of the distributional effects and potential use of the revenue of the property tax in place in 2012 represent a useful benchmark for the policy making process. Currently the Italian government is confronted with the Delega Fiscale, a legislative document that considers reforms to the property tax among other taxes, calling for an update of cadastral values to reflect market value to achieve equity and to strengthen the use of property taxes in local government finance (Keen et al., 2012).

\section{The empirical modelling}

The modelling framework we adopt in this paper allows us to estimate the incentive effects of a policy reform on the labour market and the income distribution, considering two sectors (i.e. employment and self-employment), imposing the equilibrium between demand and supply and guaranteeing revenue neutrality.

We build on the most recent literature and we do combine the existing models in an innovative way along two dimensions.

First, with respect to modelling labour supply, following on Dagsvik and Strom (2006), Dagsvik et al. (2009) and Aaberge and Colombino (2013), we propose a multisectorial labour supply model. For the first time, we include self-employment in the labour supply model and we treat employment and self-employment as two separate job sectors. Self-employment has become a sort of primary entrance way in the labour market for both young and women (Berton et al., 2011). Many of these workers do indeed work as dependent workers with a pattern of hourly wage resembling the one of employed, but the self-employment contract grants more flexibility and lower payrolls, and (because of that) is privileged by entrepreneurs (Mandrone and Marocco, 2012).

Second, in order to perform the simulation under equilibrium between labour supply and demand, we extend Colombino (2013) to cover the two job sectors and to consider the revenue neutrality taking into account the detailed rules of the tax-benefit system integrating the static simulation in the equilibrium procedure.

Overall, the empirical modelling developed in this paper is made up of three main parts, described in the following subsections. 
The first part is the static microsimulation model that converts the household gross income into disposable income under "current" and "reformed" tax-benefit rules in order to evaluate the static distributive effects of the tax-benefit reform and to define the budget set used in the labour supply model. The second part is a multisectorial labour supply model that is used to estimate the preference parameters and the behavioural changes to the tax-benefit reform. The third part accounts for the equilibrium between labour supply and demand and for fiscal neutrality.

\subsection{Static microsimulation model}

In this paper we make use of the Italian component of EUROMOD, the European-wide taxbenefit microsimulation model. EUROMOD is a static microsimulation model. It combines detailed information on relevant policy rules with representative data on individual and household circumstances drawn from national household income surveys with the aim of obtaining a consistent picture of the distribution of the personal income before and after taxes. EUROMOD simulates the main social insurance contributions, income taxes and the non contributory benefits. Contributory benefits (mainly old age and disability pensions) are not simulated due to lack of information about contributory history and health conditions and are taken directly from the underlying survey (Sutherland and Figari, 2013). Our simulations are based on the Italian component of the 2010 European Union Statistics on Income and Living Conditions (EU-SILC).

One of the main features of a static microsimulation model is to compute the disposable income of individuals and their families under different scenarios, taking into account the tax-benefit policies and the way they depend on the level of individual market income and personal/household characteristics (Bourguignon and Spadaro, 2006). Considering the gross hourly wage of the decision makers and any other source of income of the family and its characteristics, EUROMOD derives the net disposable income of the family corresponding to each possible labour market alternative the decision makers can opt for, taking into account the whole tax-benefit system.

The Italian component of EUROMOD reproduces the 2009 Italian tax-benefit system and has been validated at micro and macro level comparing the results with the aggregates provided by the fiscal authority (Ceriani et al. 2014). EUROMOD has been used to perform the static simulation that is presented in Section 5 and used as a benchmark with respect to the behavioural simulations presented in Section 6.

\subsection{The multisectorial labour supply model}

We consider couples, i.e. households whose head has a partner, and singles, i.e. household whose head is single. The two partners (in couple household) or the single head-of-household are the decision-makers in our model. We do not model the behaviour of other persons who might be living in the household, i.e. their labour supply choices are treated as exogenous. Households 
can choose among jobs characterized by hours of work $h$, chosen within a feasible set $\Omega$, sector of market job $s$ (if $h>0: s=1$ employment, $s=2$ self-employment) and other characteristics (non-pecuniary attributes) $k$ (observed by the household but not by us). By including both the employed and the self-employed we are able to use a sample that is more representative - than usually done - of the overall working-age population. We write the utility function of the i-th household as follows:

$$
U_{i}=U_{i}\left(c\left(h^{\prime} w_{s}, s, I ; T\right), h, k\right)
$$

where $c\left(h^{\prime} w_{s}, s, I ; T\right)$ is the net available income given earnings $h^{\prime} w_{s}$, unearned income $I$, sector of employment $s$ and tax-benefit rule $T$. All details of the tax-benefit system are taken into account in the estimation and simulation of the model resorting to EUROMOD.

Note that $h$ and $s$ are scalars in case of a single, while in case of a couple they are defined as follows:

$$
h=\left(\begin{array}{l}
h_{F} \\
h_{M}
\end{array}\right), \quad s=\left\{\begin{array}{l}
s_{F} \\
s_{M}
\end{array}\right\}
$$

where the subscripts $\mathrm{F}$ and $\mathrm{M}$ refer to the female and the male partner respectively. Analogously, the wage rate $w_{s}$ is a scalar in case of a single, while in case of a couple is defined as

$$
w_{s}=\left(\begin{array}{l}
w_{S_{F}} \\
w_{S_{M}}
\end{array}\right)
$$

In view of the empirical application, the utility attained by household $i$ on a job of type $(h, s)$, given the tax-benefit regime $T$, is assumed to have the form

$$
V_{i}\left(c\left(h^{\prime} w_{s}, s, I ; T\right), h\right)+\varepsilon_{i}
$$

where $V_{i}\left(c\left(h^{\prime} w_{s}, s, I ; T\right), h\right)$ is the systematic part (containing observed variables) of the utility function and $\varepsilon_{i}$ is a random variable that measures the effect of the optimally chosen (unobserved) characteristics $k$.

Let $g_{i}(h, s)$ denote the number (or the density) of jobs of type $(h, s)$ in household $i$ 's opportunity set. By assuming that $\varepsilon_{i}$ is i.i.d. Type I Extreme Value, the probability that household $i$ is matched to a job of type $(h, s)$, for $h>0$, turns out to be ${ }^{3}$ (e.g. Aaberge et al. 1999):

\footnotetext{
${ }^{3}$ In eq. (5), $j$ and $x$ are summation indices denoting respectively the job sectors and the hours of work of the feasible set $\Omega$.
} 


$$
P_{i}(h, s)=\frac{\exp \left\{V_{i}\left(c\left(h^{\prime} w_{s}, s, I ; T\right), h\right)\right\} g_{i}(h, s)}{\exp \left\{V_{i}(c(0,0, I ; T), 0)\right\}+\sum_{j=1}^{2} \sum_{x>0, x \in \Omega} \exp \left\{V_{i}\left(c\left(x^{\prime} w_{j}, j, I ; T\right), x\right)\right\} g_{i}(x, j)}
$$

For $h=0$, the probability of not working is obtained from (5) replacing the numerator with $\exp \left\{V_{i}(c(0,0, I ; T), 0)\right\}$, where $c(0,0, I ; T)$ is the disposable income due to non-labour income $I$.

Once we have estimated the utility function, we can replace $T$ with, say, $T^{\prime}$ in expression (5) in order to simulate the new choices given a new tax-benefit rule $T$ '. Such a probability accounts for the demand side of the market and then for the equilibrium through the density $g(h, s)$ (see Colombino, 2013) and can be interpreted as a Conditional Logit model where the systematic utility components are weighted by a measure of “availability” $g(h, s)$.

\section{Empirical specification and estimation results}

The choice set $\Omega$ of hours each individual can choose among, is assumed, for each sector $s$, to be represented by three alternative weekly working hours $\Omega=\left\{h_{1}, h_{2}, h_{3}\right\}$, where $h_{1}, h_{2}, h_{3}$ are random values drawn from the hours interval $1 \div 26$ (part time), $27 \div 52$ (full time), $52 \div 80$ (extra time). The not working condition is represented by $h_{0}=0$.

We estimate the labour supply models of couples and singles separately. In the case of singles we have 7 alternatives, while in the case of couple, who make joint labour-supply decision, we combine the choice alternatives of two partners, thus getting 49 alternatives.

When computing the income available on any particular job $(h, s)$ we face the problem that the wage rates of sector $s$ are observed only for those who work in sector $s$. To deal with this issue, we estimate sector-gender-specific wage equations to predict hourly wages for the jobs in the employment sector and in the self-employment sector adopting a two-stage selection-correction procedure consistent with the distributional assumption made for the random utility function (Dagsvik and Strøm 2006).

First, we estimate the parameter-vectors $b_{1}$ and $b_{2}$ with the following multinomial logit model, where $s=1$ if individual $i$ is an employee, $s=2$ if individual $i$ is self-employed and $s=0$ if individual $i$ in not working:

$$
P_{s}=\frac{e^{\mathbf{X}_{i} b_{s}}}{\sum_{s=1}^{2} e^{\mathbf{X}_{i} b_{s}}}
$$

The vector $\boldsymbol{X}_{i}$ includes personal characteristics influencing the choice of work: age, age square, education (considering lower, higher and tertiary education), marital status, number of children 
of different age range (i.e. 0-3, 4-6, 7-10), and a variable including the amount of non labour income.

Then, we estimate by OLS the parameters (on the subsample of individuals that work in sector $s$ differentiated by gender) of the logarithm of the hourly wage taking into account the selection problem:

$$
\ln w_{i, s}=z_{i} \beta_{s}-\rho_{s} \ln \hat{P}_{i, s}+u_{i, s}
$$

The logarithm of the wage rate is assumed to depend linearly on the row vector of variables $\mathbf{z}_{i}$ including: age, age square, education (considering lower, higher and tertiary education), and the unemployment of the region of household residence. $\hat{P}_{i, s}$ is the probability of being in sector $s$ computed on the basis of the estimates $\hat{b}_{1}$ and $\hat{b}_{2}$ obtained from eq. (6) and works as selectioncorrection term.

Last, we impute to every observation the wages by sector (s), computed as follows:

$$
\hat{w}_{i, s}=\exp \left(z_{i} \hat{\beta}_{s}+\hat{u}_{i, s}\right)
$$

where $u_{i, s}$ is a random draw from the normal term with mean 0 and variance equal to the estimated variance of $u_{i, s}$. The parameters $b_{s}$ and $\beta_{s}$ are gender-specific, i.e. they are estimated on the subsamples of females and males. The results of each step are reported in Appendix A.

In order to specify the systematic part of the utility function we adopt a (linear in parameters) quadratic form:

$$
V_{i}\left(c\left(h^{\prime} w_{s}, s, I ; T\right), h\right)=\mathbf{Y}\left(h^{\prime} w_{s}, s, I ; T\right) \gamma+\mathbf{L}(h) \lambda
$$

where:

$\mathbf{Y}\left(h w_{s}, S, I ; T\right)$ is a row vector including household disposable income on a job of type $(h, s$,$) given$ the tax-benefit rule T, its square and its interaction with the household size. When $h=s=0$ (i.e. not working), the net disposable income is given by non-labour income $I$, if any.

$\mathbf{L}(h)$ is a row vector including the leisure time (defined as the total number of available weekly hours (80) minus the hours of work $h$ ) for both partners, its square and the interaction with household disposable income, age (and age square), presence of children of different age range (i.e. >0, 0-6, 7-10), and leisure time of the partner.

We specify the opportunity density as follows: 


$$
g(h, s)=\exp \{\mathbf{D}(h, s) \boldsymbol{\delta}\}
$$

where $\mathbf{D}(h, s)$ is a row vector of dummy variables referring to participation, part-time, and fulltime (depending on $h$ belonging to a range of given values) in each sector $s$ and for each partner-

In the above vectors, turning to the singles, the specification of the utility function and the definition of variables are the same as for the couples, but refer to a single individual.

Given the specifications (9) and (10) and the definitions above, the probability that household $i$ is matched to a job of type $\left(h{ }^{\prime} w_{s}, s\right)$ is:

$$
P_{i}(h, s)=\frac{\exp \left\{\mathbf{Y}_{i}\left(h^{\prime} w_{s}, s, I ; T\right) \gamma+\mathbf{L}_{i}(h) \lambda+\mathbf{D}_{i}(h, s) \boldsymbol{\delta}\right\}}{\exp \left\{\mathbf{Y}_{i}(0,0, I ; T) \gamma+\mathbf{L}_{i}(0) \lambda+\mathbf{D}_{i}(0,0) \boldsymbol{\delta}\right\}+\sum_{j=1}^{2} \sum_{x>0, x \in \Omega} \exp \left\{\mathbf{Y}_{i}\left(x^{\prime} w_{j}, j, I ; T\right) \gamma+\mathbf{L}_{i}(x) \lambda+\mathbf{D}_{i}(x, j) \boldsymbol{\delta}\right\}}
$$

In identifying the decision-makers, we adopted the following criterion. We select all the individuals in the age range 18-59 not retired or disabled. Among them, for each household, we then select the oldest individual either if he/she is a single or if he/she cohabits with a partner in the same age range and is neither disabled nor retired. In this way, we end up with a sample of decision makers made up of 6,282 couples and 6,067 singles (3,273 males and 2,794 females). Together with their relatives, these individuals represent almost 68 per cent of the overall population, a larger share of population than usually accounted for in labour supply analysis, due to the inclusion of self-employed workers and individuals living with other "non-decision makers" whose labour supply is considered as exogenous.

By construction, the decision-makers are relatively young: the average age among couples is 44 for men and 41 for women, while for singles is about 37 . The inactivity rates are however quite high with respect to other European countries, especially among women. Indeed the inactivity condition characterizes the 6 per cent of men in couple, the 15 per cent of single men, the 23 per cent of single women and the 37 per cent of women in couple (Table 1). Among workers, selfemployment is quite widespread. The incidence of self-employed work ranges between 11 per cent and 25 per cent confirming a pattern that marks the Italian job market. Part-time positions are instead limited, they involve only a small percentage of women in dependent work. The average male dependent worker works about 40-41 hours per week versus the 44-47 hours of self-employed, while among women the average hours of work per week become 34-37 if employee and 40-42 if self-employed. 
Table 1 - Occupational status and hours of work of decision makers

\begin{tabular}{l|rrrr|rrrr}
\hline & \multicolumn{3}{c|}{ Occupational status (\%) } & \multicolumn{3}{c}{ Average hours of work per week } \\
\cline { 2 - 10 } & \multicolumn{2}{c}{ Couples } & \multicolumn{2}{c|}{ Single } & \multicolumn{2}{c}{ Couples } & \multicolumn{2}{c}{ Single } \\
& Men & Women & Men & Women & Men & Women & Men & Women \\
\hline Inactive & $6 \%$ & $37 \%$ & $15 \%$ & $23 \%$ & 0 & 0 & 0 & 0 \\
Employee & $69 \%$ & $52 \%$ & $63 \%$ & $63 \%$ & 40.9 & 34.2 & 40 & 36.7 \\
Self-employed & $25 \%$ & $11 \%$ & $22 \%$ & $14 \%$ & 46.6 & 39.9 & 44.4 & 41.7 \\
\hline
\end{tabular}

Source: our elaborations.

The parameters' estimates for couples and singles are reported in Tables B.1 and B.2 of Appendix B. They determine the marginal utility of income and leisure taking into account the preference heterogeneity captured by the demographic characteristics (age and number of children grouped by their age) and the opportunity density parameters. As expected from the economic theory, the coefficients of income and its square indicate increasing and diminishing marginal utility of income. The coefficients of leisure indicate increasing marginal utility of time spent not in work (diminishing as hours of leisure increase for women in couple and single). On average, households value disposable income and leisure positively.

\subsection{The equilibrium model}

In order to account for market equilibrium conditions we follow Colombino (2013), and adopt a procedure that is specifically appropriate for the estimated model: the labour market equilibrium comes through the adjustment of the coefficients of participation dummies (i.e. $\mathbf{D}(h, s)$ ) that take into account the demand of employee and of self-employed workers.

Previous attempts to incorporate equilibrium conditions in a discrete choice model setting are found in Creedy and Duncan (2005) and Peichl and Siegloch (2012) who complement a discrete choice model of labour supply by a model of labour demand. The procedure adopted there, however, would not be consistent with a matching model (as the one we adopt) that simultaneously includes a representation of both labour supply and labour demand.

In our setting, as a response to the change in tax-transfer policy regime, the number of people willing to work as employee and self-employed changes and the demand for these positions has to vary accordingly. Indeed, by assumption, the mutual consistency of agents' choices implies that the number of the available jobs be equal to the number of workers willing to be matched to these jobs. After the tax policy reform, the equilibrium between the demand and the supply in the two markets is reached through an adjustment of wages. As the average wages for employee and self-employed change, the estimated coefficients of the participation dummies in the estimated labour supply model change and so does the labour supply. 
For simplicity, let us assume that $\mathbf{D}(h, s)$ contains only the two dummies for market jobs in sector s. ${ }^{4}$ Colombino (2013) shows that, under certain assumptions, the coefficients of the dummies $\left(\boldsymbol{\delta}_{s}\right)$ can be given the following interpretation:

$$
\boldsymbol{\delta}_{s}=\ln \frac{J_{s}}{H_{s}}
$$

where $s$ is the sector of market job, $J_{s}$ is the number of available market jobs in sector $s$ (employee and self-employed) and $H_{s}$ is a normalization constant. In equilibrium the number of available market jobs must be equal to number of households willing to be matched to those jobs. If we model the number of available market jobs as a function of the average wage rates $\bar{w}_{s}$, the wage elasticity of the demand $-\eta$ and the constants $K_{s}$,

$$
J_{s}=K_{s} \bar{w}_{s}^{-\eta}
$$

we get

$$
\boldsymbol{\delta}_{s}=\ln \frac{J_{s}}{H_{s}}=\ln \frac{K_{s} \bar{w}_{s}^{-\eta}}{H_{s}}
$$

Given the observed values of $J_{s}$ and $\bar{w}_{s}$, the estimated $\boldsymbol{\delta}_{s}$ and the imputed value of $\eta$, we can retrieve the constants $H_{s}$ and $K_{s}$. The equilibrium procedure consists of iteratively finding the average wage rate that equates the number of available jobs (determined by equation (13)) to the expected number of households willing to be matched to those jobs (determined through expressions (11) and (14) ).

The wage elasticity of the demand $\eta$ is set at -0.5 , which is the predicted benchmark value for Southern European countries based on a recent meta-regression analysis on own-wage elasticities of labor demand for European countries (Licther et al., 2013).

The revenue neutrality

In order to assure that the amount of total revenues will be equal to the pre-reform setting, we iterate the labour market equilibrium procedure and change the policy parameters in order to reach both equilibria simultaneously.

The public budget constraint (PBC) is calculated on the overall population as

PBC $=\sum_{i} \sum_{h, s}\left[\operatorname{Taxes}_{\mathrm{i}}\left(h^{\prime} w, s, I\right)-\right.$ Benefits $\left._{\mathrm{i}}\left(h^{\prime} w, s, I\right)\right] \times$ wght $_{\mathrm{i}} \times P_{i}(h, s)$

\footnotetext{
${ }^{4}$ For the treatment of more general cases see Colombino (2013).
} 
where $i$ is individual, $h$ ' $w$ is labour income and $s$ is the sector, $I$ is non labour income. The observations are weighted by wght to report aggregates to the population levels.

We impose the PBC post-reform (under fiscal rules T') qual to the PBC pre-reform (under fiscal rules T):

$$
\mathrm{PBC}_{\mathrm{T}}=\mathrm{PBC}_{\mathrm{T}^{\prime}}
$$

by modifying the parameters that raises the current personal income tax credits for employee and self-employed. In such a way, the resources redistributed to low earner individuals, considering the behavioural reactions of the working age population, are obtained by the new property tax paid by households on their main and other residences without generating additional public deficit.

\subsection{An overview of the empirical model}

To sum up, the iteration algorithm to get equilibrium between supply and demand - respectively for employment and self-employment sectors - and guaranteeing revenue neutrality involves the following steps:

1) run the static microsimulation model (EUROMOD) to get the disposable income associated to each possible working alternative the individuals face under the current fiscal system $(\mathrm{T})$ and determine the mean wages for each sector $\left(\bar{w}_{s}\right)$;

2) run the labour supply model to estimate the preference parameters of couples and singles and the coefficients of the participation dummies $\boldsymbol{\delta}_{s}$ that allow to retrieve the parameters $H$ and $K$ in equation (14) used to account for the demand side effects of the reforms;

3) run the static microsimulation model (EUROMOD) to get the disposable income associated to each possible working alternative the individuals face under the reformed fiscal system (T');

4) simulate the labour supply reactions to the change in disposable income (derived at step 3)) by applying the preference parameters estimated at step 2);

5) modify the coefficients of the participation dummies $\boldsymbol{\delta}_{s}$ (equation 12) according to the variation in the average sector-specific wage to grant the equality between the demand and the supply of workers; all other estimated coefficients (obtained in step 2) remain constant;

6) compute the adjustments in the policy parameters in order to get the revenue neutrality.

7) repeat steps 3 up to 6 iteratively till reaching contemporaneously the equilibrium in the labour market and the revenue neutrality. 


\section{Labour supply elasticities}

The proposed policy reform affects disposable income of the individuals and, consequently, the labour market choices (type of work and hours of work) of the ones of them whose labour supply is modelled, i.e. the decision-makers (see Section 3.2). In order to provide a synthetic illustration of the behavioural implications of the model estimates as reported in Appendix B, in Table 2 we present the elasticity of participation (the percentage change in the participation rate over the percentage change in the gross wage rate) and the total elasticity of hours (the percentage change in total hours worked over the percentage change in the gross wage rate). The difference between total elasticity of hours and elasticity of participation gives the elasticity at the intensive margin (i.e. the percentage change in hours worked by those at work).

The elasticities have been computed by applying a 1 per cent increase in the gross wages (of employee and self-employed respectively) of each individual, simulating the individual responses and then aggregating them into average values by marital status and gender.

Table 2 - Unconditional elasticities

\begin{tabular}{|c|c|c|c|c|c|c|}
\hline & \multicolumn{4}{|c|}{ Couples } & \multicolumn{2}{|c|}{ Single } \\
\hline & \multicolumn{2}{|c|}{ Men } & \multicolumn{2}{|c|}{ Women } & Men & Women \\
\hline & Direct & Cross & Direct & Cross & Direct & Direct \\
\hline Elasticity of participation & 0.049 & 0.001 & 0.251 & 0.046 & 0.062 & 0.188 \\
\hline Total elasticity of hours of work & 0.071 & 0.002 & 0.283 & 0.056 & 0.071 & 0.209 \\
\hline
\end{tabular}

Note: Elasticities calculated numerically as the responses to a $1 \%$ uniform increase in gross wages. Source: our elaborations.

The estimated labour supply elasticities of participation are rather low for men ( 0.05 if in couple and 0.06 if single) and much higher for women ( 0.25 if in couple and 0.19 if single). The average total elasticities of hours of work do not differ substantially from the ones computed on participation, revealing that most of the labour supply responses are found at the extensive margin. Table 2 also reveals that cross-elasticities, although smaller than direct ones, are somehow relevant in the case of women. In particular, on average they are positive revealing a pattern of complementarity, with an increase in the male partner's wage determining an increase in female working hours, already found in the literature with respect to Italy. This complementarity pattern supports the importance of modeling joint household decision.

The above values reported for individuals in couple are in line with the ones found in the recent literature (e.g. Bargain et al., 2014 based on 1995 data) while those for singles are more difficult to compare given the selection criteria used in the different studies and the evolution of such demographic groups over time. 


\section{Tax shifting: a hypothetical reform}

Using the extra revenue of the property tax introduced in 2012 (as explained in section 2) we propose to make the existing tax credits on employment and self-employment income more generous and refundable, resembling the provision of in-work benefits currently in place in most of the European countries and in the US (Immervoll and Pearson, 2009). We start with multiplying the current tax credits by a factor (alfa $=2.1$ ) that guarantees revenue neutrality in a static scenario. Under this simulation scenario, employees get up to 3864 euro if their annual taxable income is up to 8000 euro; between 8000 and 15000 the new tax credit is phased out at 20 per cent (i.e. every additional euro gained the credit is reduced by 0.2 ); above 15000 per year nothing changes with respect to the baseline scenario and the tax credit is decreasing with taxable income. Self-employed workers get up to 2318 euro if their annual taxable income is below 8000 euro, reduced with a taper rate equal to 20 per cent up to 12000 euro per year, and nothing changes with respect to the baseline scenario if taxable income is above 12000 euro per year (see Table 3 for details).

Table 3 - Tax credits for employees and self-employed under current and hypothetical tax system

\begin{tabular}{|c|c|c|}
\hline & $\begin{array}{c}\text { Current tax credit } \\
\text { Non refundable, } € \text { per year }\end{array}$ & $\begin{array}{l}\text { Proposed new tax credit } \\
\text { Refundable, } € \text { per year }\end{array}$ \\
\hline \multirow[t]{4}{*}{ Employee } & 1840 if taxable income $<=8000 €$ & alfa*1840 if taxable income $<=8000 €$ \\
\hline & & $\begin{array}{l}\text { Reduced with a taper rate equal to } 20 \% \\
\text { with taxable income between } 8000 € \text { and } \\
15.000 €\end{array}$ \\
\hline & & $\begin{array}{l}\text { Decreasing with taxable income between } \\
15000 € \text { and } 55.000 €\end{array}$ \\
\hline & $\begin{array}{l}\text { Decreasing with taxable income } \\
\text { between } 8000 € \text { and } 55.000 €\end{array}$ & \\
\hline \multirow[t]{3}{*}{ Self-employed } & 1104 if taxable income $<=4800 €$ & alfa*1104 if taxable income $<=8000 €$ \\
\hline & & $\begin{array}{l}\text { Reduced with a taper rate equal to } 20 \% \text { with } \\
\text { taxable income between } 8000 € \text { and } 12.000 €\end{array}$ \\
\hline & $\begin{array}{l}\text { Decreasing with taxable income } \\
\text { between } 4800 € \text { and } 55.000 €\end{array}$ & $\begin{array}{l}\text { Decreasing with taxable income between } \\
12000 € \text { and } 55.000 €\end{array}$ \\
\hline
\end{tabular}

Note. In the current scenario, the tax credit corresponds to the threshold multiplied by the lowest marginal tax rate (i.e. $8000 * 23 \%$ for the employee and $4800 * 23 \%$ for the self-employed) and guarantees a no-tax area for those with employment or self-employment income equal to the threshold. In the proposed new scenario, initially the factor alfa is set equal to 2.1 in order to guarantee revenue neutrality in a static scenario. The factor alfa is then calibrated in order to guarantee revenue neutrality under labour market equilibrium. Source: our elaboration. 
For gross labour income from employment below 25000 euro per year (horizontal axis), Figure 1 shows the net income after personal income tax under the current tax regime (solid line) and the new reformed scenario regime (dashed line), where it is clear the additional income provided through the new refundable tax credit. In particular, employees with a current theoretical (non refundable) tax credit of 1840 euro per year in our simulation receive 3560 per year as tax credit, in the form of negative income tax if their tax liability is lower than the tax credit entitlement.

\section{Figure 1. After tax income under current tax system and reformed scenario, employee}

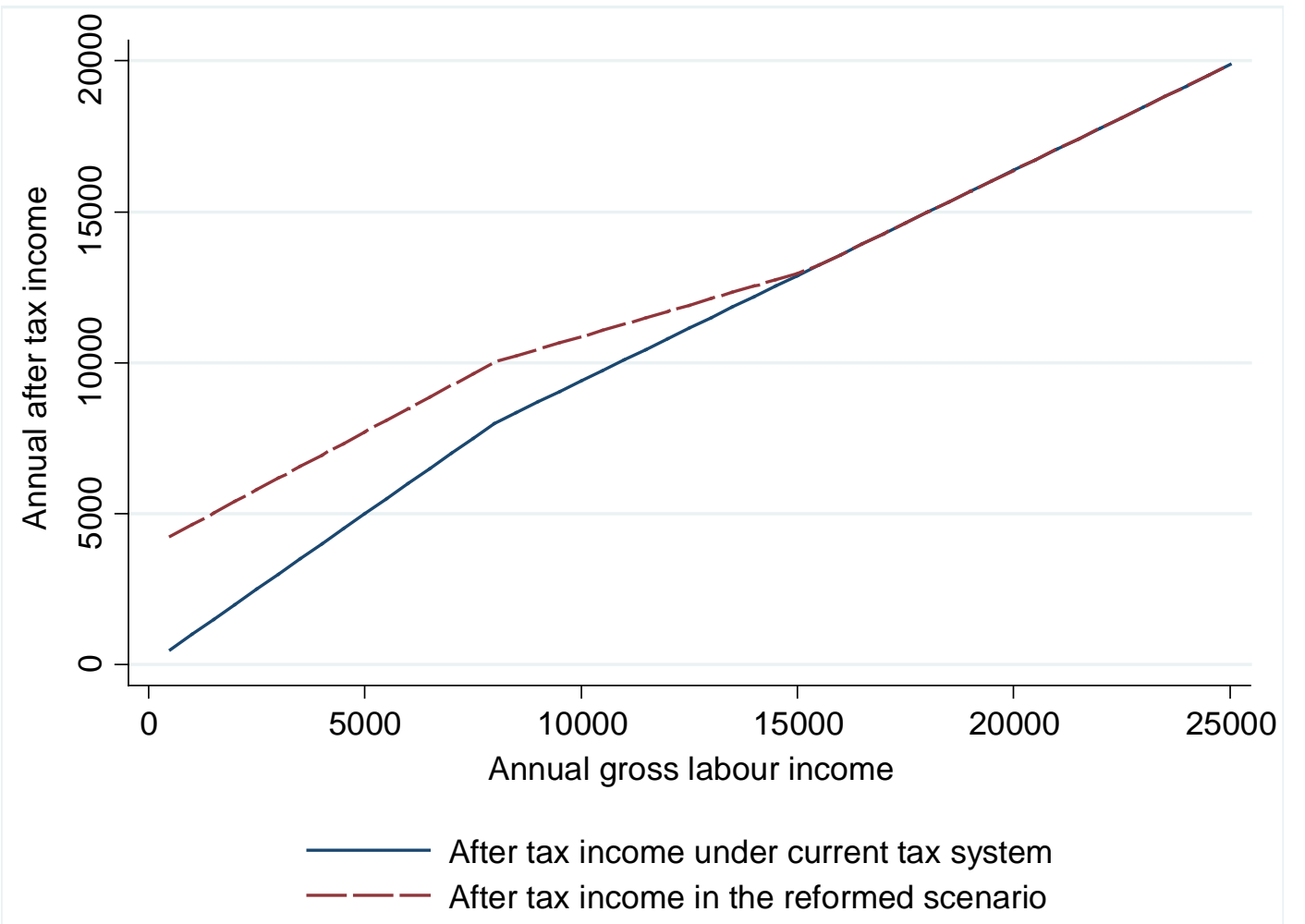

Source: our simulations on gross labour income, assumed to be the only income source of a hypothetical individual. Family and expenditures related tax credits not considered.

Table 4 reports the static redistributive effects of such a reform on the overall population. The tax shifting from labour income to property is expected to have distributional consequences on the overall population due to the widespread homeownership rates (almost 70 per cent of Italian families own the main residence (Figari et al. 2012), while secondary dwellings often belong to individuals in the top part of the income distribution) and the tax relief attributed to individuals with low labour incomes.

The introduction of the new property tax (Column a) is responsible for a reduction of disposable income in all decile groups. The reduction is about $1.3 \%$ in the first decile (due to the relatively 
higher tax burden for the owners characterized by low liquidity), $1 \%$ in the second decile and then goes up progressively up to $1.63 \%$ in the tenth decile.

Once the extra revenue is used to provide low income earners with the new tax credit (Column b), disposable income increases by 8 per cent in the first decile. Positive increases are found for individuals up to the seventh decile, while richer deciles witness a reduction in their disposable income up to 1.5 per cent.

Table 4 - Static redistributive effects of tax shifting by decile group

Decile groups Percentage change of average equivalent disposable income due to

Property tax Property tax and new tax credits

(a)

(b)

\begin{tabular}{ccc}
\hline 1 & -1.32 & 7.62 \\
2 & -0.92 & 1.92 \\
3 & -0.79 & 1.79 \\
4 & -0.91 & 1.7 \\
5 & -1.06 & 1.06 \\
6 & -1.06 & 0.85 \\
7 & -1.09 & 0.21 \\
8 & -1.12 & -0.21 \\
9 & -1.2 & -0.64 \\
10 & -1.67 & -1.51 \\
\hline
\end{tabular}

Note: Static redistributive effects computed on overall population without taking into account any behavioural reaction. Decile groups defined on the basis of equivalent disposable income in the pre-reform scenario. Source: our elaborations.

\section{The labour market equilibrium effects of tax shifting}

The proposed policy change affects the disposable income of our population and consequently their supply of work both at the intensive and the extensive margins. In the following we report the changes in the occupational status, hours of work and disposable income taking into account labour supply and equilibrium effects separately.

The different steps outlined above have been iterated recursively in order to find the average wages and the tax policy parameters that lead simultaneously to the equilibrium between the demand and the supply of market jobs and the revenue neutrality of the proposed policy.

In order to restore the equilibrium between the demand and the supply of market jobs and the revenue neutrality, the average wage for employees and self-employed has to change of about -0.51 per cent and -1.11 per cent respectively. These results for employee and self-employed 
support the inclusion in our model of self-employed sector, which in the past was usually considered not responding to wage variations. Furthermore, the multiplicative parameter "alfa" of the tax credits used in a static scenario for guaranteeing revenue neutrality, decreases from 2.1 to 1.9545 in the equilibrium scenario.

Table 5 shows the variations in the occupational status of individuals and in hours of work that follow the introduction of the reform taking into account the labour supply reactions and equilibrium conditions. Inactivity rates are expected to decrease among women of about 3 per cent and among men of about 2 per cent. In the wake of this, the number of employees is expected to increase for both men and women. However, the increase in dependent work among men partially depends also on the simultaneous shift of some self-employed to dependent work. Under labour market equilibrium (which implies overall revenue neutrality as well), the overall increase in the labour supply is reduced by around 30 per cent for women and single men, with a larger contraction for men in couples of about 50 per cent.

The variation in the number of hours of work is due to the joint effect of extensive and intensive margins changes in and to the change in the proportions of employees and self-employed. It turns out that the expected hours of work by the employees increase for both men and women, while they decrease for self-employed men.

Table 5. Change in the occupational status and in the hours of work by marital status, gender and sector.

\begin{tabular}{|c|c|c|c|c|c|c|c|c|}
\hline & \multicolumn{4}{|c|}{ Labour supply model } & \multicolumn{4}{|c|}{ Equilibrium model } \\
\hline & \multicolumn{2}{|c|}{ Couples } & \multicolumn{2}{|c|}{ Single } & \multicolumn{2}{|c|}{ Couples } & \multicolumn{2}{|c|}{ Single } \\
\hline & Men & Women & Men & Women & Men & Women & Men & Women \\
\hline \multicolumn{9}{|c|}{ Changes of labour market status (\%) } \\
\hline Inactive & -1.59 & -2.56 & -0.97 & -3.02 & -0.76 & -1.69 & -0.69 & -1.95 \\
\hline Employee & 0.18 & 1.2 & 0.28 & 0.5 & 0.16 & 0.68 & 0.19 & 0.24 \\
\hline Self-emplı & -0.13 & 2.98 & -0.16 & 2.61 & -0.28 & 2.48 & -0.07 & 2.07 \\
\hline \multicolumn{9}{|c|}{ Variation of hours worked (\%) } \\
\hline Employee & 0.07 & 0.52 & 0.2 & 0.01 & 0.08 & 0.08 & 0.11 & -0.19 \\
\hline Self-empl & -0.19 & 2.37 & -0.22 & 2.14 & -0.36 & 1.87 & -0.14 & 1.62 \\
\hline Total & 0 & 0.88 & 0.08 & 0.43 & -0.05 & 0.43 & 0.05 & 0.17 \\
\hline
\end{tabular}

Notes: Percentage variations computed within the same category. Source: our elaborations on sample of decision makers and those belonging to their households. 
The proposed tax policy reform mainly affects low income groups and women. Table 6 shows the expected variations in the supply of work by income deciles. Among married women in the first income decile, the supply of work increases of about +3.42 per cent. Among single women and men of the same income group, it increases of about +2.01 per cent and about +0.87 per cent respectively.

Married women are the most reactive group, both because of their high labour supply elasticity and because they are more likely to be entitled to the new generous tax credit - their earnings being on average lower than men's. Although remaining positive, the increase in their labour supply rapidly diminishes for the upper income decile groups till reaching values lower than 1 percentage point from the 5th income decile group on. Men in couples and singles (both men and women) face a positive change in the supply of hours of work in the first two decile groups and a negative - although small - change in the middle of the distribution, where the disincentive at the intensive margin due to the generosity of the tax credit seems to prevail.

Under labour market equilibrium and revenue neutrality, the direction of the variations in labour supply is confirmed for all individual by marital status and decile groups, although the negative variation in the middle of the distribution is reinforced mainly due to the compression of the wage rate.

Table 6. Percentage variation in hours of work by marital status, gender and income decile

\section{Labour supply model} Equilibrium model

\begin{tabular}{c|cccc|ccccc}
\multirow{2}{*}{$\begin{array}{c}\text { Decile } \\
\text { groups }\end{array}$} & \multicolumn{2}{c}{ Couples } & \multicolumn{2}{c}{ Single } & \multicolumn{2}{c}{ Couples } & \multicolumn{2}{c}{ Single } \\
\hline 1 & 0.13 & 3.42 & 0.87 & 2.01 & 0.07 & 2.61 & 0.64 & 1.30 \\
2 & 0.03 & 2.70 & 0.14 & 0.20 & -0.04 & 1.86 & 0.03 & -0.17 \\
3 & -0.04 & 2.00 & -0.02 & -0.11 & -0.09 & 1.26 & -0.10 & -0.31 \\
4 & -0.03 & 1.21 & -0.03 & -0.01 & -0.07 & 0.64 & -0.07 & -0.15 \\
5 & -0.01 & 0.97 & -0.03 & -0.02 & -0.05 & 0.45 & -0.05 & -0.13 \\
6 & -0.02 & 0.70 & -0.03 & 0.00 & -0.06 & 0.27 & -0.03 & -0.09 \\
7 & -0.01 & 0.57 & -0.03 & -0.02 & -0.04 & 0.19 & -0.03 & -0.08 \\
8 & -0.01 & 0.21 & -0.01 & 0.12 & -0.05 & -0.12 & -0.01 & 0.06 \\
9 & 0.01 & 0.06 & 0.01 & 0.09 & -0.03 & -0.18 & 0.01 & 0.04 \\
10 & 0.03 & -0.06 & 0.05 & 0.09 & -0.04 & -0.27 & 0.07 & 0.08 \\
\hline
\end{tabular}

Source: our elaborations on sample of decision makers and those belonging to their households.

In the following Table 7 we consider the redistributive effects of the tax shifting under a static scenario and then taking into account labour supply and equilibrium effects respectively. 
Without considering any behavioral reaction, individuals in the first decile group face a substantial increase in their disposable income, due to the generosity of the tax credit to which they are entitled to: individuals in couple face an increase of around 7 per cent, single men of more than 10 per cent and single women of around 9 per cent. Overall, the redistribution implied by the tax shifting from labour income to property make individuals experience positive changes in the bottom half of the income distribution, while those in the upper decile groups experience a lost in their disposable income up to 1 per cent.

The labour supply responses lead to an additional increase in the household equivalent disposable income for all individuals at the bottom of the distribution, while the disincentive effect at the intensive margin observed above, determines small negative changes in income for single men and women in the middle and upper part of the income distribution.

Once we account for the equilibrium effects and the fiscal neutrality, the increase in the household disposable income at the bottom of the income distribution results to be lower than in the static scenario but it is still relevant, with changes due to the overall tax shifting reform larger than 6 per cent for the individual in the poorest decile groups.

Table 7. Redistributive effects. Percentage variation in the household disposable income in different models by marital status, gender and income decile

\begin{tabular}{r|ccc|ccc|ccc}
\hline & \multicolumn{3}{|c|}{ Static } & \multicolumn{2}{c|}{ Labour Supply model } & \multicolumn{3}{c}{ Equilibrium model } \\
$\begin{array}{r}\text { Decile } \\
\text { groups }\end{array}$ & Couple & \multicolumn{2}{c}{ Single } & Couple & \multicolumn{2}{c}{ Single } & Couple & \multicolumn{2}{c}{ Single } \\
& & Men & Women & & Men & Women & & Men & Women \\
\hline 1 & 7.47 & 10.49 & 8.60 & 8.66 & 11.43 & 10.56 & 6.00 & 7.97 & 6.99 \\
2 & 3.77 & 4.69 & 2.70 & 4.51 & 4.94 & 2.78 & 2.42 & 2.46 & 0.67 \\
3 & 2.10 & 1.88 & 2.11 & 2.58 & 1.93 & 1.95 & 0.89 & 0.17 & 0.39 \\
4 & 1.24 & 0.82 & 0.40 & 1.53 & 0.81 & 0.33 & 0.12 & -0.67 & -0.72 \\
5 & 1.00 & 0.50 & 0.61 & 1.22 & 0.49 & 0.54 & -0.06 & -0.61 & -0.39 \\
6 & 0.48 & -0.09 & -0.34 & 0.63 & -0.10 & -0.37 & -0.51 & -0.86 & -1.18 \\
7 & 0.17 & -0.36 & -0.54 & 0.26 & -0.37 & -0.58 & -0.73 & -1.12 & -1.27 \\
8 & -0.01 & -0.36 & -0.56 & 0.03 & -0.36 & -0.53 & -0.90 & -1.01 & -1.12 \\
9 & -0.51 & -0.77 & -0.88 & -0.49 & -0.76 & -0.82 & -1.31 & -1.31 & -1.34 \\
10 & -1.16 & -1.23 & -1.49 & -1.16 & -1.19 & -1.41 & -1.86 & -1.66 & -1.79 \\
\hline
\end{tabular}

Note: Redistributive effects computed on sample of decision makers and those belonging to their households. Decile groups defined on the basis of equivalised disposable income in the prereform scenario (weighted by probabilities associated to each working alternative). Source: our elaborations.

The reform is responsible for a slight increase in the average disposable income in the static scenario and considering the labour supply reactions, due to the redistribution implied from home-owners (and in particular pensioners) to low earner workers. At the same time, it induces a 
slight reduction in the average household disposable income when the equilibrium is taken into account due to the reduction in average wage which is not fully compensated by the positive labour supply reactions (Table 8). Notwithstanding, the overall income distribution appears more equal with a substantial reduction of the Gini index of around one percentage point, moving from 0.25 in the pre reform scenario to 0.24 after the reform.

Table 8. Average household disposable income and income inequality

Pre reform Post reform

Static Labour supply model Equilibrium model

Average equivalent household disposable income (euro per month)

\begin{tabular}{lrlll} 
Couples & 1328 & 1336 & 1339 & 1323 \\
Single men & 1361 & 1363 & 1364 & 1351 \\
Single women & 1051 & 1060 & 1063 & 1049 \\
$\begin{array}{l}\text { Income inequality } \\
\text { Gini coefficient }\end{array}$ & & & \\
\hline
\end{tabular}

Source: our elaborations on sample of decision makers and those belonging to their households.

\section{Conclusions}

We have considered a hypothetical tax shifting reform in Italy, using the revenue of the tax on house property (IMU, actually implemented in 2012) for increasing tax credits on low incomes and making them refundable. Refundable tax credits in fact introduce a negative income which is expected to provide a more effective income support and at the same time give better incentives to work for low wage households.

Leaving aside potential effects on housing markets which are anyway assumed to be limited in a country like Italy characterized by an inelastic housing market and very low mobility, in order to evaluate the reform we developed a multisectorial structural model of household labour supply which takes into account the labour market equilibrium conditions and ensures fiscal neutrality. The analysis adds to the existing literature on ex ante evaluation of policy reforms as it simultaneously: a) encompasses a multisectorial perspective in order to better capture the heterogeneity in the workers population; b) adopts a modelling framework fully consistent with comparative static analysis considering the labour market equilibrium conditions; c) allows for revenue neutrality of the proposed policy, by means of integrating the detailed simulation of the tax-benefit system at each step of the programming.

The simulations confirm the expectations. Namely, there is an increase in employment and available income, especially for households in the lowest income deciles, and also an improvement in inequality indexes. The equalizing effect of the reform appears to be 
undisputable. More ambiguous are the efficiency effects: employment and income tend to increase (at least in the lowest deciles), but the average income suffers a modest decrease when equilibrium is taken into account.

Nevertheless, some caveats need to be borne in mind in the interpretation of the results. First, the equilibrium simulation exercises are conducted under the hypothesis that the elasticity of labour demand is equal to -0.5 , a somehow prudential assumption based on the estimated average elasticity for the Southern European countries, although other values can be tested. Second, a more comprehensive normative evaluation procedure should be based on individual and social preferences (e.g. Aaberge and Colombino 2013), not just on employment and income. These developments are left for future work. 


\section{References}

Aaberge, R. and U. Colombino (2013), Using a Microeconometric Model of Household Labour Supply to Design Optimal Income Taxes, Scandinavian Journal of Economics, 115(2), 449-476.

Aaberge, R. and U. Colombino (2014), Microsimulation and Labour Supply Models: a survey and an interpretation, in O’Donogue C. (Ed.) Handbook of Microsimulation, Emerald.

Aaberge, R., Colombino, U. and S. Strøm (1999), Labour Supply in Italy: An Empirical Analysis of Joint Household Decisions, with Taxes and Quantity Constraints, Journal of Applied Econometrics, 14, 1999, 403-422.

Arnold, J. M., Brys, B., Heady, C., Johansson, Å., Schwellnus, C. and L. Vartia (2011), Tax Policy for Economic Recovery and Growth, The Economic Journal, 121: F59-F80

Bargain, O., Orsini K. and A. Peichl (2014), Comparing Labour Supply Elasticities in Europe and the US: New results, Journal of Human Resources, forthcoming.

Berton F., Devicenti F. and L. Pacelli (2011), Are Temporary Jobs a Port of Entry into Permanent Employment? Evidence from Matched Employer-Employee Data, International Journal of Manpower, 32(8), 879-899.

Bourguignon, F. and A. Spadaro (2006), Microsimulation as a tool for evaluating redistribution policies, Journal of Economic Inequality, 4:1, 77-106.

Ceriani L., Figari F., and C. Fiorio (2014), EUROMOD Country Report, Italy 2009-2013. https://www.iser.essex.ac.uk/euromod/resources-for-euromod-users/country-reports

Colombino, U. (2013), A new equilibrium simulation procedure with discrete choice models, International Journal of Microsimulation, 6(3), 25-49.

Creedy, J. and A. Duncan (2005), Aggregating Labour Supply and Feedback Effects in Microsimulation, Australian Journal of Labour Economics, 8(3), 277-290.

Dagsvik, J. and S. Strøm (2006), Sectoral Labour Supply, Choice Restrictions and Functional Form, Journal of Applied Econometrics, 21(6), 803-826.

Dagsvik, J., Locatelli M. and S. Strøm (2009), Tax Reform, Sector-specific Labor Supply and Welfare Effects, Scandinavian Journal of Economics, 111(2), 299-321.

European Commission (2012), Possible reforms of real estate taxation: criteria for successful policies. European Economy Occasional Papers 119. 
Figari, F., A. Paulus, H. Sutherland, P. Tsakloglou, G. Verbist and F. Zantomio (2012), Taxing the benefit of homeownership. Distributional effects of including imputer rent in taxable income, IZA Discussion Paper 6493.

Immervoll, H. and Pearson, M. (2009), A good time for making work pay? Taking stock of inwork benefits and related measures across the OECD, IZA Policy Paper No. 3, Bonn: IZA.

International Monetary Fund (2013), Taxing Times, World Economic and Financial Surveys, Fiscal Monitor October 2013.

Keen, M., R. de Mooij, L. Eyraud, J. Tyon, S. Bond, and L. Walters (2012), Italy: The Delega Fiscale and the Strategic Orientation of Tax Reform, International Monetary Fund, Fiscal Affairs Department.

Lichter, A., A. Peichl, and S. Siegloch (2013), Labor demand elasticities in Europe: a metaanalysis, Neujobs Working Paper No. D10.7

Longobardi, E. (2013), On the Role of the Property Tax in Financing Local Expenditure: The Case of Italy, Paper presented to the Copenhagen Workshop, September 12-13.

Mandrone, E. and M. Marocco (2012), La Variante Italiana della Flessibilità, ISFOL Research Paper $1 / 2012$.

Mirrlees, J., Adam, S., Besley, T., Blundell, R., Bond, S., Chote, R., Gammie, M., Johnson, P., Myles G., and J. Poterba (2011), Eds, Tax by Design: the Mirrlees Review, Oxford University Press, Oxford.

Norregaard, J. (2013), Taxing Immovable Property. Revenue Potential and Implementation Challenges, International Monetary Fund, WP 13/129

OECD (2009), Moving beyond the crisis: using tax policy to support financial stability, June.

OECD (2014), Revenue Statistics. Paris: OECD Publishing.

Peichl, A., and S. Siegloch (2012), Accounting for labor demand effects in structural labor supply models, Labour Economics, 19(1), 129-138.

Sutherland, H. and F. Figari (2013), EUROMOD: the European Union tax-benefit microsimulation model, International Journal of Microsimulation, 6(1), 4-26.

Verbist, G. and F. Figari (2014), The Redistributive Effect and Progressivity of Taxes Revisited: An International Comparison across the European Union, FinanzArchiv - Public Finance Analysis, 70(3): 405-429. 


\section{Appendix A}

Table A.1 Multinomial logit estimates (equation 6)

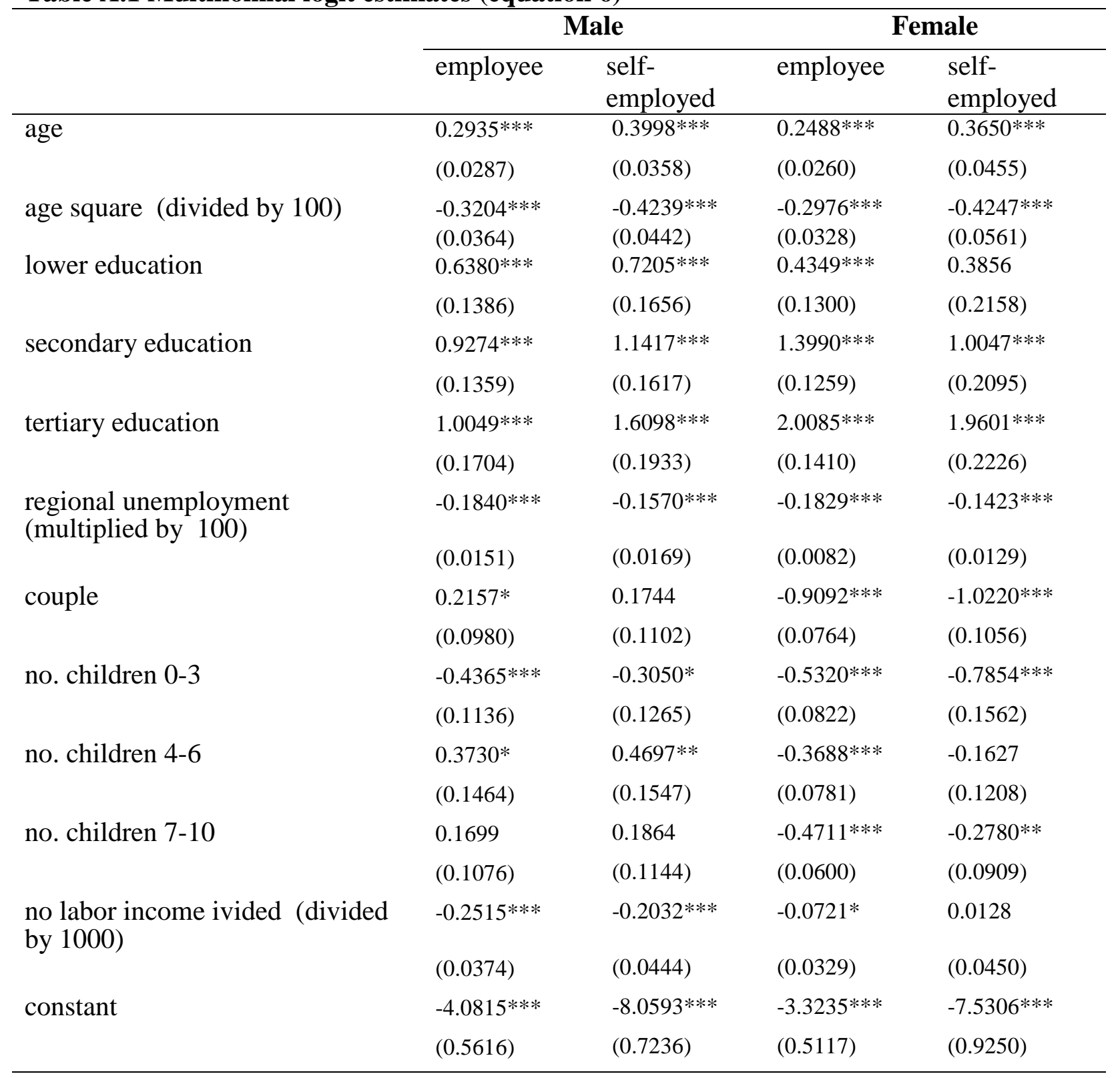

\begin{tabular}{lcc} 
n. obs. & 8689 & 7393 \\
LR chi2(22) & 750.33 & 1713.97 \\
Prob > chi2 & 0.0000 & 0.0000 \\
Pseudo R2 & 0.0515 & 0.1226 \\
Log likelihood & -6915.23 & -6135.23 \\
\hline Notes: Base outcome: not working Standard error in parentheses. Significance level: * for $\mathrm{p}<.05, * *$ for $\mathrm{p}<.01$, and \\
$* * *$ for $\mathrm{p}<.001$ &
\end{tabular}


Table A.2. OLS estimates of the wage equation (equation 7).

\begin{tabular}{|c|c|c|c|c|}
\hline & \multicolumn{2}{|c|}{ Male } & \multicolumn{2}{|c|}{ Female } \\
\hline & employee & $\begin{array}{l}\text { self- } \\
\text { employed }\end{array}$ & employee & $\begin{array}{l}\text { self- } \\
\text { employed }\end{array}$ \\
\hline \multirow[t]{2}{*}{ age } & $0.0356 * * *$ & 0.0100 & $0.0217^{* *}$ & -0.0443 \\
\hline & $(0.0058)$ & $(0.0336)$ & $(0.0068)$ & $(0.0344)$ \\
\hline \multirow[t]{2}{*}{ age square (divided by 100) } & $-0.0233^{* *}$ & 0.0036 & -0.0079 & 0.0598 \\
\hline & $(0.0071)$ & $(0.0362)$ & $(0.0085)$ & $(0.0406)$ \\
\hline \multirow[t]{2}{*}{ lower education } & $0.0899 * * *$ & 0.0733 & -0.0293 & 0.0017 \\
\hline & $(0.0261)$ & $(0.0762)$ & $(0.0439)$ & $(0.1481)$ \\
\hline \multirow[t]{2}{*}{ secondary education } & $0.3022 * * *$ & $0.2679 * *$ & $0.2522 * * *$ & 0.1468 \\
\hline & $(0.0251)$ & $(0.0868)$ & $(0.0424)$ & $(0.1445)$ \\
\hline \multirow[t]{2}{*}{ tertiary education } & $0.6197 * * *$ & $0.5789 * * *$ & $0.5430 * * *$ & $0.4848^{* *}$ \\
\hline & $(0.0287)$ & $(0.1182)$ & $(0.0446)$ & $(0.1708)$ \\
\hline \multirow{2}{*}{$\begin{array}{l}\text { region unemployment } \\
\text { (multiplied by 100) }\end{array}$} & $-0.0325^{* * *}$ & $-0.0484 * * *$ & $-0.0132 * * *$ & -0.0057 \\
\hline & $(0.0037)$ & $(0.0062)$ & $(0.0028)$ & $(0.0094)$ \\
\hline \multirow[t]{2}{*}{$-\ln \hat{P}_{j}$} & 0.1548 & -0.7708 & 0.1724 & 1.4203 \\
\hline & $(0.3396)$ & (1.9899) & $(0.1734)$ & $(0.9336)$ \\
\hline \multirow[t]{2}{*}{ constant } & $1.3578^{* * *}$ & $2.0448^{* * *}$ & $1.5025^{* * *}$ & $2.4494 * * *$ \\
\hline & (0.1739) & $(0.3396)$ & $(0.1521)$ & $(0.6203)$ \\
\hline n. obs & 5582 & 1972 & 3599 & 716 \\
\hline $\mathrm{F}$ & 268.54 & 34.19 & 139.88 & 11.05 \\
\hline Prob $>$ F & 0 & 0 & 0 & 0 \\
\hline R-squared & 0.2522 & 0.1086 & 0.2142 & 0.0985 \\
\hline Adj R-squared & 0.2513 & 0.1054 & 0.2127 & 0.0896 \\
\hline RootMSE & 0.4136 & 0.64852 & 0.4223 & 0.70712 \\
\hline
\end{tabular}

Notes: Standard error in parentheses. Significance level: ${ }^{*}$ for $\mathrm{p}<.05$, $* *$ for $\mathrm{p}<.01$, and $* * *$ for $\mathrm{p}<.001$ 


\section{Appendix B}

Tables B.1 and B.2 report the maximum likelihood estimates of the parameters of equation 11) for couples and singles.

Table B.1 - Conditional Logit estimates - couples

\begin{tabular}{|c|c|c|c|}
\hline Model component & Variable & Coef. & Std. Err. \\
\hline * Opportunity & Employee_Male & $1.5221 * * *$ & 0.4294 \\
\hline \multirow[t]{11}{*}{ density $\boldsymbol{g}$} & Self-employed_Male & $2.2265 * * *$ & 0.4206 \\
\hline & Employee_Female & $-2.69 * * *$ & 0.3846 \\
\hline & Self-employed_Female & $-1.416 * * *$ & 0.3754 \\
\hline & Part-time_Employee_Male & $-1.795 * * *$ & 0.1811 \\
\hline & Full-time_Employee_Male & $2.3752 * * *$ & 0.0997 \\
\hline & Part-time_Self-employed_Male & $-3.516 * * *$ & 0.2231 \\
\hline & Full-time_Self-employed_Male & $0.7659 * * *$ & 0.0941 \\
\hline & Part-time_Employee_Female & $1.2507 * * *$ & 0.2162 \\
\hline & Full-time_Employee_Female & $2.8032 * * *$ & 0.2025 \\
\hline & Part-time_Self-employed_Female & $-1.613 * * *$ & 0.2139 \\
\hline & Full-time_Self-employed_Female & $0.6913 * * *$ & 0.1762 \\
\hline \multirow[t]{3}{*}{$\mathbf{Y}$ vector } & Household_Disposable_income (divided by 1000) & $1.5468 * * *$ & 0.2326 \\
\hline & Hosuhold_Disposable_income ${ }^{2}$ (divided by $1 \mathrm{e}+06$ ) & -0.0202 & 0.0158 \\
\hline & Household_size×Household_disposable_income (divided by 1000) & $-0.1439 * * *$ & 0.0233 \\
\hline \multirow[t]{22}{*}{$\mathbf{L}$ vector } & Leisure_Male & $0.1211 * * *$ & 0.0321 \\
\hline & Leisure_Male ${ }^{2}$ (divided by 1000) & 0.2452 & 0.0002 \\
\hline & Leisure_Female & $0.2384 * * *$ & 0.2122 \\
\hline & Leisure_Female $^{2}$ (divided by 1000) & $-1.0476 * * *$ & 0.2514 \\
\hline & Leisure_Male×Household_disp_income (divided by 1e+06) & 0.5379 & 1.6834 \\
\hline & Leisure_Female×Household_disp_income (divided by 1e+06) & $-3.2076 * *$ & 1.2426 \\
\hline & Leisure_Male×Age_Male & $-0.005 * * *$ & 0.0012 \\
\hline & Leisure_Female×Age_Female & $-0.005 * * *$ & 0.0008 \\
\hline & Leisure_Male×Age_Male2 (divided by 1000) & $0.0590 * * *$ & 0.0145 \\
\hline & Leisure_Female×Age_Female2 (divided by 1000) & $0.0691 * * *$ & 0.0101 \\
\hline & Leisure_Male×No. Children & $-0.004 *$ & 0.0017 \\
\hline & Leisure_Female×No. Children & $0.0036 * *$ & 0.0012 \\
\hline & Leisure_Male×No. Children0-6 & $0.0046 *$ & 0.0022 \\
\hline & Leisure_Male×No. Children7-10 & -0.002 & 0.0025 \\
\hline & Leisure_Female×No. Children0-6 & $0.0039 *$ & 0.0015 \\
\hline & Leisure_Female×No. Children7-10 & $0.0044 * *$ & 0.0016 \\
\hline & Leisure_Female×No. Leisure_Male & $0.0003 * * *$ & 0.0001 \\
\hline & n. obs. & 307818 & \\
\hline & LR chi2(32) & 17486 & \\
\hline & Prob > chi2 & 0 & \\
\hline & Pseudo R2 & 0.3576 & \\
\hline & Log likelihood & -15706 & \\
\hline
\end{tabular}

Notes: Standard error in parentheses. Significance level: * for $\mathrm{p}<.05$, ** for $\mathrm{p}<.01$, and ${ }^{* * *}$ for $\mathrm{p}<.001$ 
Table B.2 - Conditional Logit estimates - singles

\begin{tabular}{|c|c|c|c|c|c|}
\hline \multirow{2}{*}{ Model component } & & \multicolumn{2}{|l|}{ Male } & \multicolumn{2}{|c|}{ Female } \\
\hline & & Coeff. & Std. Err. & Coeff. & Std. Err. \\
\hline \multirow{6}{*}{$\begin{array}{l}\text { * Opportunity } \\
\text { density } \boldsymbol{g}\end{array}$} & Employee & $15332 *$ & 0.6376 & $-4,9141 * * *$ & 0.6281 \\
\hline & Self_employed & $1.8316 * *$ & 0.6267 & $-3.7570 * * *$ & 0.6220 \\
\hline & Part-time_Employee & $-1.9476 * * *$ & 0.2541 & $1.3255 * * *$ & 0.2794 \\
\hline & Full-time_Employee & $2.2396 * * *$ & 0.1622 & $2.7549 * * *$ & 0.2527 \\
\hline & Part-time_Self-employed & $-3.3897 * * *$ & 0.3005 & $-1.6785 * * *$ & 0.3267 \\
\hline & Full-time_Self-employed & $0.9586 * * *$ & 0.1604 & $0.7834 * * *$ & 0.2303 \\
\hline \multirow[t]{3}{*}{$\mathbf{Y}$ vector } & Disposable income (divided by 1000) & $0.6955 * *$ & 0.2483 & $1.5778 * * *$ & 0.2650 \\
\hline & Disposable income $^{2}$ (divided by $1 \mathrm{e}+06$ ) & $-0.0732 *$ & 0.0300 & $-0.1308 * * *$ & 0.0374 \\
\hline & Household size×Disp_income (divided by 1000 . & 0.0923 & 0.0545 & 0.0315 & 0.0504 \\
\hline \multirow[t]{13}{*}{$\mathbf{L}$ vector } & Leisure & $0.2134 * * *$ & 0.0303 & $0.3948 * * *$ & 0.0368 \\
\hline & Leisure $^{2}$ (divided by 1000) & 0.1098 & 0.3436 & $-2.3755 * * *$ & 0.4007 \\
\hline & Leisure×Disposable income (divided by $1 \mathrm{e}+06$ ) & -4.6612 & 2.6190 & $-6.5925 * *$ & 2.4874 \\
\hline & Leisure×Age & $-0.0077 * * *$ & 0.0008 & $-0.0077 * * *$ & 0.0008 \\
\hline & 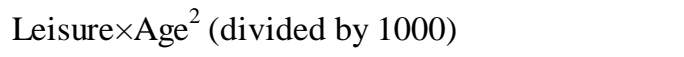 & $0.9373 * * *$ & 0.1004 & $0.9256 * * *$ & 0.1068 \\
\hline & Leisure×No. Children & -0.0063 & 0.0079 & $0.0088 * *$ & 0.0029 \\
\hline & Leisure $\times$ No. Children 0-6 & -0.0249 & 0.0219 & 0.0041 & 0.0044 \\
\hline & Leisure×No. Children 7-10 & -0.0221 & 0.0187 & 0.0043 & 0.0049 \\
\hline & n. obs. & 22911 & & 19558 & \\
\hline & LR chi2(17) & 4728.03 & & 3776.24 & \\
\hline & Prob > chi2 & 0 & & 0 & \\
\hline & Pseudo R2 & 0.3712 & & 0.3473 & \\
\hline & Log likelihood & -4004.95 & & -3548.75 & \\
\hline
\end{tabular}

Notes: Standard error in parentheses. Significance level: ${ }^{*}$ for $\mathrm{p}<.05$, ${ }^{* *}$ for $\mathrm{p}<.01$, and ${ }^{* * *}$ for $\mathrm{p}<.001$ 


\section{Latest CeRP Working Papers}

\begin{tabular}{|c|c|}
\hline $\mathrm{N}^{\circ} 149 / 15$ & $\begin{array}{l}\text { Flavia Coda Moscarola } \\
\text { Ugo Colombino } \\
\text { Francesco Figari } \\
\text { Marilena Locatelli }\end{array}$ \\
\hline $\mathrm{N}^{\circ} 148 / 15$ & $\begin{array}{l}\text { Flavia Coda Moscarola } \\
\text { Elsa Fornero } \\
\text { Steinar Strøm }\end{array}$ \\
\hline $\mathrm{N}^{\circ} 147 / 14$ & $\begin{array}{l}\text { Matteo Morini } \\
\text { Simone Pellegrino }\end{array}$ \\
\hline $\mathrm{N}^{\circ} 146 / 14$ & $\begin{array}{l}\text { Mariacristina Rossi } \\
\text { Eva Sierminska }\end{array}$ \\
\hline $\mathrm{N}^{\circ} 145 / 14$ & $\begin{array}{l}\text { Johannes G. Hoogeveen } \\
\text { Mariacristina Rossi } \\
\text { Dario Sansone }\end{array}$ \\
\hline $\mathrm{N}^{\circ} 144 / 14$ & Elsa Fornero \\
\hline$N^{\circ} 143 / 14$ & $\begin{array}{l}\text { Kees de Vaan } \\
\text { Daniele Fano } \\
\text { Herialt Mens } \\
\text { Giovanna Nicodano }\end{array}$ \\
\hline $\mathrm{N}^{\circ} 142 / 14$ & $\begin{array}{l}\text { Elisabetta Cagna } \\
\text { Giulio Casuccio }\end{array}$ \\
\hline $\mathrm{N}^{\circ} 141 / 14$ & $\begin{array}{l}\text { Massimo Baldini } \\
\text { Costanza Torricelli } \\
\text { Maria Cesira Urzì Brancati }\end{array}$ \\
\hline $\mathrm{N}^{\circ} 140 / 14$ & $\begin{array}{l}\text { Cecilia Boggio } \\
\text { Elsa Fornero } \\
\text { Henriette Prast } \\
\text { Jose Sanders }\end{array}$ \\
\hline $\mathrm{N}^{\circ} 139 / 14$ & $\begin{array}{l}\text { Laura Bianchini } \\
\text { Margherita Borella }\end{array}$ \\
\hline $\mathrm{N}^{\circ} 138 / 13$ & Claudio Morana \\
\hline $\mathrm{N}^{\circ} 137 / 13$ & Claudio Morana \\
\hline $\mathrm{N}^{\circ} 136 / 13$ & Anna Lo Prete \\
\hline $\mathrm{N}^{\circ} 135 / 13$ & $\begin{array}{l}\text { Rik Dillingh } \\
\text { Henriette Prast } \\
\text { Mariacristina Rossi } \\
\text { Cesira Urzì Brancati }\end{array}$ \\
\hline$N^{\circ} 134 / 13$ & $\begin{array}{l}\text { Annamaria Lusardi } \\
\text { Olivia S. Mitchell }\end{array}$ \\
\hline $\mathrm{N}^{\circ} 133 / 13$ & $\begin{array}{l}\text { Annamaria Lusardi } \\
\text { Pierre-Carl Michaud } \\
\text { Olivia S. Mitchell }\end{array}$ \\
\hline
\end{tabular}

Shifting Taxes from Labour to Property. A Simulation under Labour Market Equilibrium

Absenteeism, Pension Reforms and Grandmothers

Personal Income Tax Reforms: a Genetic Algorithm Approach

Single again? Asset and portfolio changes due to widowhood shock

Drivers of performance in primary education in Togo

Economic-financial literacy and (sustainable) pension reforms: why the former is a key ingredient for the latter

A Reporting Standard for Defined Contribution Pension Plans

Equally-weighted Risk Contribution Portfolios: an empirical study using expected shortfall

Family ties: occupational responses to cope with a household income shock

Seven Ways to Knit Your Portfolio: Is Investor Communication Neutral?

Cognitive Functioning and Retirement in Europe

Insights on the global macro-finance interface: Structural sources of risk factors fluctuations and the cross-section of expected stock returns

New Insights on the US OIS Spreads Term Structure During the Recent Financial Turmoil

Inequality and the finance you know: does economic literacy matter?

The psychology and economics of reverse mortgage attitudes: evidence from the Netherlands

The Economic Importance of Financial Literacy: Theory and Evidence

Optimal Financial Knowledge and Wealth Inequality

The full series is available at: http://www.cerp.carloalberto.org/category/publications/working-papers/ 